\title{
Analisa Investasi The Akavia Indekost Residences Ngaliyan - Semarang
}

\author{
Adelia Munawaroh dan Christiono Utomo \\ Jurusan Teknik Sipil, Fakultas Teknik Sipil, Institut Teknologi Sepuluh Nopember (ITS) \\ Jl. Arief Rahman Hakim, Surabaya 60111 Indonesia \\ e-mail: christiono@ce.its.ac.id
}

\begin{abstract}
Abstrak- Dalam berinvestasi hal pertama yang menjadi bahan pertimbangan pastilah apakah investasi yang akan dilakukan akan menjanjikan keuntungan atau tidak. Akavia Indekost didesign dengan konsep perumahan mewah dan dilengkapi dengan fasilitas yang membuat nyaman dan mempermudah aktifitas penghuninya sehingga diharapkan dapat memenuhi kebutuhan masyarakat yang membutuhkan tempat kos. Pasar yang dituju adalah investor, karyawan, maupun pelajar. Indekost ini akan dibangun secara keseluruhan sehingga membutuhkan biaya yang cukup besar untuk menyelesaikannya. Oleh karena itu, pembangunan Indekost ini harus memenuhi kelayakan dari segi finansial. Tujuan dari penelitian ini adalah melakukan analisis kelayakan The Akavia Indekost Ngaliyan-Semarang yang direncanakan dari aspek finansial. Metodologi yang dipergunakan dalam penelitian ini adalah pengumpulan data, pengolahan data, analisa pendapatan dan pengeluaran, aliran kas serta meninjau aspek finansial dengan metode Net Present Value ( NPV), Internal Rate of Return ( IRR ), dan Payback Periode (PP), serta melakukan analisa sensitivitas terhadap biaya investasi, tarif jual, suku bunga pinjaman, dan tingkat okupansi jual. Hasil yang diperoleh adalah NPV bernilai positif sebesar Rp 502.305.139 dengan tingkat suku bunga $11 \%$. Nilai IRR sebesar $15 \%>$ arus pengembalian yang diinginkan yaitu sebesar $11 \%$, dan PP pada tahun kedua. Sedangkan untuk hasil analisa sensitivitas antara variabel terhadap NPV diketahui bahwa The Akavia Indekost layak jika kenaikan biaya investasi tidak lebih dari 3\%, kenaikan harga jual tidak lebih dari $3 \%$, kenaikan bunga pinjaman tidak lebih dari 1,5\%, dan occupancy penjualan unit tidak lebih dari $96 \%$.
\end{abstract}

Kata Kunci- Analisa Investasi, Kelayakan Finansial, The Akavia Indekost Residence.

\section{PENDAHULUAN}

$\mathrm{D}$ ALAM berinvestasi hal pertama yang menjadi bahan pertimbangan pastilah apakah investasi yang akan dilakukan akan menjanjikan keuntungan atau tidak. Usaha cluster indekost merupakan inovasi baru dan pertama dikota Semarang dimana merupakan kompleks perumahan yang difungsikan sebagai jasa sewa tempat tinggal sementara dan didesign untuk memberikan passive income secara maksimal bagi masing masing pemilik unitnya. Di design dengan konsep perumahan mewah dan dilengkapi dengan fasilitas yang membuat nyaman dan mempermudah aktifitas penghuninya. Jasa sewa tempat tinggal sementara ini memang menjanjikan apalagi jika terletak di kawasan yang sangat potensial semisal kawasan kampus, rumah sakit, sekolah, pasar. Semua lokasi ini sangat menjanjikan bagi para pengelola bisnis Indekost, pasar yang dituju adalah investor, karyawan, maupun pelajar karena memang akan ada banyak pegawai, karyawan, anak sekolah, sampai mahasiswa yang membutuhkan kost.
The Akavia Indekost Residences terletak di J1.Prof. Dr. Hamka Ngaliyan Raya Semarang Barat yang menghubungkan Pusat Kota Semarang dengan kawasan industri dan pemukiman yang sedang sangat berkembang di area Bukit Semarang Baru. Terletak tepat di depan Pintu Tol Trans Jawa (seksi Semarang - Batang) sehingga akan berada tepat di depan salah satu pintu gerbang Kota Semarang. The Akavia juga terletak di antara kawasan industri, pendidikan, dan layanan kesehatan yang merupakan market yang besar untuk pasar hunian sementara. The Akavia Indekost Residence dibangun diatas tanah seluas 1,3 hektar. Dalam satu kompleks perumahan terdiri dari 28 building yang merupakan bangunan 4 lantai dan tersedia dalam 2 tipe yaitu tipe Deluxe dengan 21 kamar dan Exclusive dengan 24 kamar. Hal ini membuat PT.Cita Kayana Semesta selaku Developer optimis mengembangkan usaha Indekost di kota Semarang yang dapat memenuhi kebutuhan tempat tinggal sementara bagi pegawai, karyawan, anak sekolah, sampai mahasiswa yang bekerja atau bersekolah disekitar atau dekat dengan lokasi The Akavia Indekost Residence.

Biaya yang diperlukan dalam pembangunan proyek ini pun sangatlah besar, sehingga diperlukan analisa kelayakan dalam hal finansial agar modal investasi yang telah dikeluarkan dapat kembali sesuai rencana dengan mendapat keuntungan yang diharapkan. Modal yang akan dipakai yaitu $60 \%$ modal pinjaman dan $40 \%$ modal sendiri dengan asumsi masa investasi selama 5 tahun. Analisa aspek finansial digunakan untuk menganalisis kelayakan suatu usaha dari segi finansial melalui keputusan pengalokasian sumber daya yang terbatas kedalam peluang investasi yang ada [1], sehingga dapat memberikan keuntungan yang maksimal. Analisis finansial ditinjau untuk mengetahui tingkat kelayakan investasi dengan menggunakan kriteria kelayakan investasi yaitu, Net Present Value (NPV), Internal Rate Of Return (IRR), dan Pacback Periode (PP), apakah investasi proyek ini sudah layak dari segi finansial atau perlu dianalisa tingkat sensitivitasnya terhadap parameter-parameter yang ada.

Tujuan dilakukannya tugas akhir ini adalah untuk melakukan analisis kelayakan proyek pembangunan The Akavia Indekost Residences Ngaliyan-Semarang yang direncanakan dari aspek finansial serta melakukan analisis untuk menganalisa pengaruh tingkat sensitivitas proyek pembangunan The Akavia Indekost Residences Ngaliyan Semarang terhadap beberapa parameter yang dipakai dalam analisa ini antara lain biaya investasi, perubahan harga jual, bunga pinjaman, dan okupansi jual. 


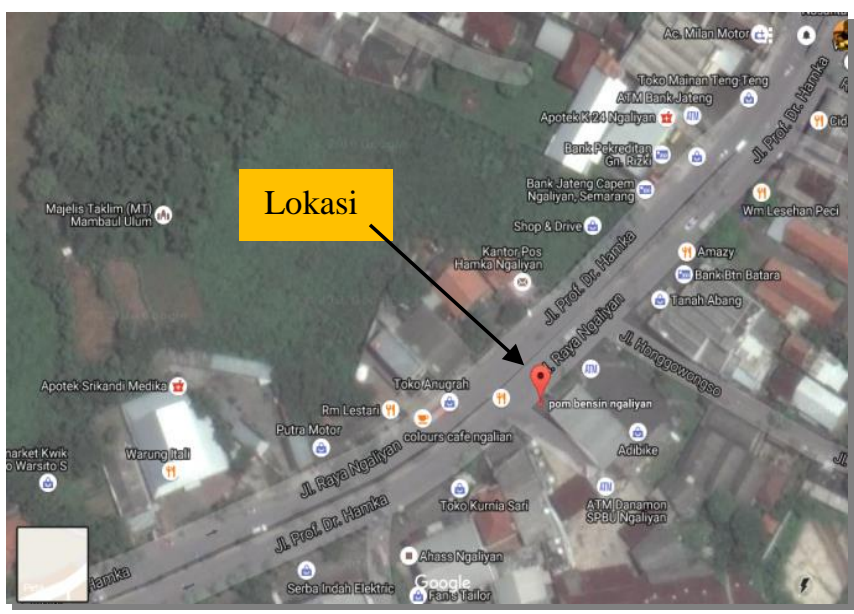

Gambar 1. Lokasi The Akavia Indekost Residences

Sumber: Google earth

\section{KONSEP DAN PENELITIAN TERDAHULU}

\section{A. Konsep Penelitian}

Penelitian ini adalah sebuah studi yang membahas tentang analisa investasi untuk mengetahui seberapa besar kelayakan investasi proyek The Akavia Indekost Residence. Analisa investasi ditinjau dari aspek finansial yang kemudian dianalisa menggunakan metode Net Present Value ( NPV), Internal Rate of Return ( IRR ), serta Payback Periode ( PP ). Pendapatan dalam analisa ini adalah penjualan tipe unit hunian. Modal yang dipakai yaitu $60 \%$ modal pinjaman dan $40 \%$ modal sendiri. Selanjutnya dilakukan analisa sensitivitas terhadap tingkat biaya investasi, perubahan harga jual, bunga pinjaman, dan okupansi jual agar mengetahui alternatif mana yang paling sensitif terhadap perubahan variabelnya.

\section{B. Penelitian Terdahulu}

1. Sari dan Utomo (2012) dengan judul analisa pembeayaan kerjasama pemerintah dan swasta pada proyek Sidoarjo town square untuk mengetahui keuntungan antara pemerintah dan swasta serta perbandingan tingkat keuntungan antara keduanya selama masa investasi. Metode yang dipakai yaitu NPV dan PI, serta analisa sensitivitas terhadap masa investasi [2].

2. Khaer dan utomo (2012) dengan judul pengaruh tingkat hunian pada keputusan investasi proyek hotel santika gubeng Surabaya. Analisa kelayakan investasi terhadap tingkat okupansi dengan menggunakan metode NPV dan IRR [3].

3. Prastiwi dan Utomo (2013) dengan judul kelayakan investasi perumahan green semanggi mangrove Surabaya ditinjau dari aspek finansial. Metode yang dipakai yaitu NPV, IRR dan PI serta analisa sensitivitas terhadap tingkat pengembalian investasi dengan umur 5 tahun [4].

4. Putra, Utomo, dan Nurcahyo (2013) dengan judul analisa pembeayaan investasi proyek apartemen puncak kertajaya, alternatif modal yang dipakai yaitu $100 \%$ modal sendiri, $20 \%$ modal sendiri dan $80 \%$ pinjaman, $50 \%$ modal sendiri dan $50 \%$ pinjaman, $80 \%$ modal sendiri dan 20\% pinjaman. Metode yang dipakai NPV [5].
5. Nufaili dan Utomo (2014 ) pada penelitian dengan judul analisa investasi hotel pessona Makassar, metode yang dipakai yaitu NPV, IRR, PP dan menganalisa sensitivitas dengan merubah tingkat hunian (okupansi) dan tarif sewa ruangan [6].

6. Ningsih dan Utomo (2014) dengan judul analisa pembiayaan investasi apartemen puri park view tower E kebon jeruk-Jakarta Barat. Sumber pembiayaan menggunakan 4 alternatif $100 \%$ modal sendiri, $70 \%$ pinjaman, $50 \%$ pinjaman dan $30 \%$ pinjaman. Metode yang dipakai adalah NPV dan IRR. Nilai ROR dan ROE digunakan untuk memperoleh peluang keuangan dari besarnya komposisi hutang yang masih meringankan pengembalian modal [7].

7. Syahrizal dan Utomo (2014) dengan judul Analisa pembiayaan investasi proyek pembangunan perumahan green pakis regency Malang. Sumber pembiayaan menggunakan beberapa alternatif yaitu $100 \%$ modal sendiri, $70 \%$ modal sendiri dan $30 \%$ pinjaman, $50 \%$ modal sendiri dan $50 \%$ pinjaman, $30 \%$ modal sendiri dan $70 \%$ pinjaman. Metode yang dipakai adalah NPV dan IRR [8].

8. Wahyudi dan Utomo (2014) dengan judul analisa investasi pada proyek pembangunan apartemen bale hinggil Surabaya. Dengan menganalisa alternatif pendapatan yang optimal dari pemilihan alternatif pendapatan sewa, jual, dan gabungan dari keduanya. Penilaian kelayakan investasi menggunakan metode NPV dan IRR, serta analisa sensitivitas terhadap alternatif pendapatan [9].

9. Listyaningsih dan Utomo (2014) dengan judul pengaruh keterlambatan pembebasan lahan terhadap keputusan investasi proyek jalan tol SurabayaMojokerto. Metode yang dipakai yaitu NPV dan IRR dan analisa sensitivitas terhadap keterlambatan pemasukan serta keterlambatan pembebasan lahan [10].

10. Iffahni dan Utomo (2015) pada penelitian dengan judul analisa investasi apartemen taman melati Surabaya. Sumber pembiayaan menggunakan dua alternatif yaitu 70\% modal Pinjaman dan 30\% modal sendiri. Menggunakan metode analisa NPV dan IRR ,serta menganalisa sensitivitas terhadap biaya investasi, tarif jual serta sewa hunian [11].

11. Maulanasari dan Utomo (2015) dengan judul analisa pembiayaan investasi properti perkantoran di Jakarta Selatan. Sumber pembiayaan menggunakan beberapa alternatif yaitu 100\% , 60\% modal sendiri dan $40 \%$ pinjaman, 50\% modal sendiri dan 50\% pinjaman, serta $40 \%$ modal sendiri dan $60 \%$ pinjaman. Menggunakan metode analisa NPV dan IRR [12].

12. Maulina dan Utomo (2016) dengan judul study kelayakan investasi apartemen gunawangsa merr Surabaya. Metode yang digunakan adalah NPV, IRR, dan PP, dengan masa investasi selama 10 tahun dan analisa sensitivitas terhadap harga jual, sewa, tarif listrik, dan biaya investasi [13].

13. Herwitasari dan Utomo (2016) dengan judul studi pengambilan keputusan investasi dengan resiko pada pengembangan proyek caspian tower, gran sungkono lagoon Surabaya, untuk mendapatkan keputusan terbaik dalam investasi dilihat dari resiko dan tingkat 
keuntungan yang didapat. Metode yang digunakan adalah NPV [14].

Terdapat beberapa persamaan mendasar berdasarkan beberapa penelitian diatas yaitu penelitian bertujuan untuk mendapatkan keputusan investasi terbaik berdasarkan kelayakan aspek finansial. Perbedaan dari beberapa penelitian diatas adalah objek penelitian dimana objek penelitian pada penelitian sebelumnya berbeda mulai dari perumahan, hotel, apartemen, perkantoran, dan ada juga yang menganalisa pengaruh keterlambatan pembebasan lahan terhadap keputusan investasi dengan objek yang dipakai adalah jalan tol. sedangkan objek pada penelitian ini adalah perumahan indekos dimana perumahan yang seluruh unitnya difungsikan sebagai tempat kos. Metode yang dipakai untuk penilaian kelayakan investasi sebagian besar sama, yaitu NPV dan IRR. Dalam penelitian ini dipakai 3 metode yaitu NPV, IRR, dan PP alternatif sumber pembiayaan $60 \%$ modal pinjaman dan $40 \%$ modal sendiri. Selain itu penelitian ini juga menganalisa sensitivitas terhadap biaya investasi, perubahan harga jual, bunga pinjaman, dan okupansi penjualan unit.

\section{METODOLOGI}

\section{A. Metode Perhitungan}

Langkah berikutnya setelah tahap analisa adalah perhitungan analisa kelayakan investasi yang meliputi :

1. Net Present Value (NPV)

Merupakan selisih antara benefit ( penerimaan ) dengan cost ( pengeluaran ) yang telah di present value kan. NPV adala present value aliran kas masuk dikurangi dengan present value aliran kas keluar [1].

Keputusan investasi adalah sebagai berikut :

NPV $>0$ usulan investasi diterima

NPV $<0$ usulan investasi ditolak

$$
\mathrm{NPV}=\quad \frac{C F 1}{(1+i)^{n_{1}}}+\frac{C F 2}{(1+i)^{n_{2}}}+\cdots \frac{C F 2}{(1+i)^{a_{T}}}-\mathrm{OI}
$$

Dimana :

$$
\text { NPV : Nilai sekarang bersih }
$$

CF1,2..n : cash flow tahun 1,2,3 sampai ke-n

$$
\begin{array}{ll}
\mathrm{i} & \begin{array}{c}
\text { cost of capital / interest rate / requiered rate } \\
\text { of return / arus pengembalian }
\end{array} \\
\mathrm{n} & \text { : umur proyek investasi } \\
\mathrm{OI} & \text { : original investment }
\end{array}
$$

\section{Internal rate of Return (IRR)}

Merupakan tingkat diskonto yang menyamakan present value aliran kas masuk dengan present value aliran kas keluar [1].

$$
I R R=i L+\frac{(i u-i l)(N P V l)}{(N P V l-N P V u)}
$$

Dimana :

$$
\begin{aligned}
& \mathrm{i}_{1}: \text { tingkat diskon }(+) \\
& \mathrm{i}_{\mathrm{u}}: \text { tingkat diskon }(-) \\
& \mathrm{NPV}_{1}: \operatorname{NPV}(+) \\
& \mathrm{NPV}_{\mathrm{u}}: \operatorname{NPV}(-)
\end{aligned}
$$

\section{Payback Periode (PP)}

$$
\text { Payback Period }=\frac{l}{A b}
$$

1 = Besarnya biaya investasi yang diperlukan

$\mathrm{Ab}=$ Keuntungan bersih yang diperoleh tiap tahunnya

\section{Analisa Sensitivitas}

Studi Kelayakan Analisa Finansial memerlukan suatu analisis sensitivitas yang berguna untuk mengkaji sejauh mana perubahan unsur-unsur dalam aspek finansial berpengaruh terhadap keputusan yang dipilih. Sensitif tidaknya suatu keputusan diambil terhadap perubahan unsurunsur tertentu. Apabila perubahan unsur-unsur mengakibatkan perubahan keputusan maka keputusan tersebut dinilai sensitif terhadap terhadap unsur yang dimaksud [15].

\section{HASIL DAN PEMBAHASAN}

\section{A. Konsep Pengembangan Perumahan}

Konsep pengembangan indekost akan direncanakan dalam 4 tahap. Pada saat ini kondisi lahan sudah merupakan lahan kosong dan direncanakan akan dimulai dibangun pada awal tahun 2017 dan ditargetkan rampung pada tahun 2018.

\section{Tahap pertama}

Dihitung pada tahun ke 0 masa investasi. Merupakan proses pembebasan lahan seluas 1,3 Ha. Harga tanah didapat dari hasil estimasi pembanding terhadap lahan yang telah terjual disekitar lokasi.

\section{Tahap kedua}

Direncanakan pada tahun pertama pembangunan gate utama + jalan paving sepanjang area Indekost, Pos jaga, 10 unit Deluxe, 3 unit Exclusive serta pembangunan fasilitas umum tahap 1.

\section{Tahap ketiga}

Direncanakan pada tahun kedua pembangunan 7 unit Deluxe dan 2 unit Exclusive, serta dilanjutkan pembangunan fasilitas umum tahap 2 .

\section{Tahap keempat}

Direncanakan pada tahun kedua pembangunan 4 unit Deluxe dan 2 unit Exclusive, serta dilanjutkan pembangunan jalan paving di depan unit Indekost

\section{B. Analisa Investasi}

Biaya investasi merupakan semua biaya awal yang dikeluarkan untuk membangun perumahan The Akavia Indekost ini. Biaya-biaya tersebut antara lain :

1. Biaya Tanah / lahan

2. Biaya Konstruksi meliputi biaya struktur dan bangunan yang meliputi komponen biaya pondasi, struktur, dinding, lantai, plafond, atap, utilitas, tata udara, finishing, interior.

3. Biaya Pembangunan Infrastruktur

4. Biaya Jasa Profesi

5. Biaya Administrasi

6. Biaya Pengembangan Fasum

\section{Analisa Pendapatan}

Pendapatan Perumahan Indekost ini diperoleh dari penjualan unit indokost tipe Deluxe dan Exclusive yang dijual seluruhnya. Harga jual masing-masing tipe unit berbeda sesuai dengan tipe dan luasnya. Estimasi harga jual objek didapatkan dengan membandingkannya dengan harga 
jual properti sejenis. Rencana penjualan unit Indekost dapat dilihat pada tabel rencana penjualan per tahun dimulai dari tahun 2017 dan direncanakan habis terjual pada tahun 2019.

Dipakai beberapa pembanding harga jual properti sejenis sekitar lokasi objek, kemudian dibandingkan dengan objek sehingga didapatkan estimasi harga jual objek.

Tabel 1.

Rencana penjualan Unit Indekost

\begin{tabular}{lcccc}
\hline \hline Type & Jumlah & $\mathbf{2 0 1 7}$ & $\mathbf{2 0 1 8}$ & $\mathbf{2 0 1 9}$ \\
\hline Deluxe & 21 & 10 & 7 & 4 \\
Exclusive & 7 & 3 & 2 & 2 \\
\hline \hline Sumber: Perhitungan
\end{tabular}

Tabel 2.

Rekapitulasi Penjualan Per-Tahun

\begin{tabular}{|c|c|c|c|}
\hline \multirow{2}{*}{ Pendapatan } & \multicolumn{3}{|c|}{ Tahun } \\
\hline & 2017 & 2018 & 2019 \\
\hline $\begin{array}{l}\text { Penjualan Unit } \\
\text { (Rp) }\end{array}$ & $\begin{array}{c}\mathrm{Rp} \\
60.983 .207 .697\end{array}$ & $\begin{array}{c}\mathrm{Rp} \\
44.179 .920 .982\end{array}$ & $\begin{array}{c}\mathrm{Rp} \\
26.836 .997 .524\end{array}$ \\
\hline
\end{tabular}

Sumber : Perhitungan

\section{Analisa Pengeluaran}

Pengeluaran pada The Akavia Indekost Residence berupa biaya operasional seperti gaji pegawai, biaya listrik, biaya air. Biaya pemasaran, dan estate management. Rekapitulasi biaya pengeluaran per-tahun dapat dilihat pada tabel dibawah ini.

Tabel 3.

Rekapitulasi Pengeluaran Per-Tahun

\begin{tabular}{lccc}
\hline \hline \multicolumn{1}{c}{ Pengeluaran } & $\mathbf{2 0 1 7}$ & Tahun & $\mathbf{2 0 1 8}$ \\
& $\mathrm{Rp}$ & $\mathrm{Ro19}$ \\
Gaji Karyawan (Rp) & 296.616 .000 & 332.209 .920 & 372.075 .110 \\
& $\mathrm{Rp}$ & $\mathrm{Rp}$ & $\mathrm{Rp}$ \\
Biaya Listrik (Rp) & 46.202 .342 & 47.984 .170 & 49.765 .997 \\
& $\mathrm{Rp}$ & $\mathrm{Rp}$ & $\mathrm{Rp}$ \\
Biaya Air (Rp) & 1.257 .120 & 1.257 .120 & 1.257 .120 \\
& $\mathrm{Rp}$ & $\mathrm{Rp}$ & $\mathrm{Rp}$ \\
Pemasaran (Rp) & 1.829 .496 .231 & 1.325 .397 .629 & 805.109 .926 \\
& $\mathrm{Rp}$ & $\mathrm{Rp}$ & $\mathrm{Rp}$ \\
Total (Rp) & 2.173 .571 .693 & 1.706 .848 .839 & 1.228 .208 .153 \\
Estate & $\mathrm{Rp}$ & $\mathrm{Rp}$ & $\mathrm{Rp}$ \\
Manajemen (Rp) & 152.458 .019 & 110.449 .802 & 67.092 .494 \\
\hline \hline
\end{tabular}

\begin{tabular}{lcc}
\hline \multirow{2}{*}{ Pengeluaran } & \multicolumn{2}{c}{ Tahun } \\
& $\mathbf{2 0 2 0}$ & $\mathbf{2 0 2 1}$ \\
\hline \multirow{2}{*}{ Gaji Karyawan (Rp) } & $\mathrm{Rp}$ & $\mathrm{Rp}$ \\
& 416.724 .124 & 466.731 .018 \\
Biaya Listrik (Rp) & $\mathrm{Rp}$ & $\mathrm{Rp}$ \\
& 51.547 .824 & 53.329 .651 \\
Biaya Air (Rp) & $\mathrm{Rp}$ & $\mathrm{Rp}$ \\
Pemasaran (Rp) & 1.257 .120 & 1.257 .120 \\
& - & - \\
Total (Rp) & $\mathrm{Rp}$ & $\mathrm{Rp}$ \\
Estate & 469.529 .068 & 521.319 .811 \\
Manajemen (Rp) & $\mathrm{Rp}$ & $\mathrm{Rp}$ \\
\hline \hline Simber : Pemitungan & 67.092 .494 & 67.092 .494 \\
\hline
\end{tabular}

Sumber : Perhitungan

\section{E. Analisa Kelayakan Investasi}

Perhitungan aliran kas menggunakan besaran MARR berdasarkan tingkat pengembalian modal sendiri dan pinjaman. Perhitungan biaya tiap tahun dihitung dengan Discount Factor (DF).

$$
\mathrm{DF}=\frac{1}{(1+i)^{n}}
$$

dimana i adalah MARR investasi dan $\mathrm{n}$ adalah tahun saat biaya tersebut dikeluarkan.

Tingkat pengembalian modal sendiri diperoleh dari tingkat suku bunga deposito beberapa Bank di Indonesia. Safe rate +/- Resiko . Tingkat pengembalian modal pinjaman adalah sebesar 11\% dengan MARR 11\%

Berdasarkan perhitungan aliran kas dengan $\mathrm{n}$ investasi selama 5 tahun diperoleh nilai NPV sebesar Rp. Rp 502.305.139 > 0 maka investasi dinyatakan layak.

\section{Internal rate of Return (IRR)}

Untuk mendapatkan nilai IRR menggunakan trial and error dengan mengubah nilai i sehingga mendapatkan nilai $\mathrm{NPV}+$ dan - , maka dicoba $\mathrm{i}=15 \%, \mathrm{i}=20 \%, \mathrm{i}=25 \%$, $\mathrm{i}=$ $20 \%$, kemudian diinterpolasi.

$$
\begin{aligned}
& \mathrm{IRR}=\mathrm{i}_{\mathrm{L}}+\left[\frac{(i u-i l)(N P V l)}{(N P V l-N P V u)}\right] \\
& =15 \%+\left[\frac{(2076-1596)(\text { Rp.43.393.297) }}{(\text { Ap 49.399.297-( }- \text { Rp 629.016.429) })}\right]=15 \%
\end{aligned}
$$

IRR 15\% > MARR 11\%, maka proyek ini dinyatakan layak dikerjakan.

\section{Payback Periode (PP)}

Untuk menentukan nilai PP digunakan trial and error dengan mendapatkan NPV + dan -, kemudian diinterpolasi.

$$
\begin{aligned}
& \mathrm{PP}=\mathrm{n}_{\mathrm{L}}+\left[\frac{(n u-n l)(\text { Kum. NPVl })}{(\text { Kum } N P V l-k u m \cdot N P V u)}\right] \\
& =2 \%+\left[\frac{(276-196)(\operatorname{Rp} 4.126 .079 .426)}{(\operatorname{Rp} 4.136 .079 .426-(-\operatorname{Rp} 4.400 .982 .246)}\right]=2 \text { thn }
\end{aligned}
$$

3. Analisa Sensitivitas

Merupakan pengukuran batas-batas perubahan yang menyebabkan keputusan investasi berubah. Parameter yang digunakan dalam penelitian ini antara lain biaya investasi, tarif jual, bunga pinjaman, dan okupansi penjualan.

Hasil analisa sensitivitas antara variabel terhadap NPV diketahui bahwa The Akavia Indekost layak jika kenaikan biaya investasi tidak lebih dari 3\%, kenaikan harga jual tidak lebih dari 3\%, kenaikan bunga pinjaman tidak lebih dari $1,5 \%$, dan occupancy penjualan unit tidak lebih dari $96 \%$

\section{KESIMPULAN}

Modal yang dipakai adalah $60 \%$ pinjaman dan $40 \%$ modal sendiri. Berdasarkan analisa investasi yang telah dilakukan dapat disimpulkan bahwa Pembangunan The Akavia Indekost Residence ini layak dari segi finansial, karena telah memenuhi beberapa kriteria. NPV bernilai positif sebesar $\mathrm{Rp}$ 502.305.139 dengan tingkat suku bunga $11 \%$. Nilai IRR sebesar $15 \%$ > arus pengembalian yang diinginkan yaitu sebesar $11 \%$, sedangkan Payback periode pada tahun ke-2 .

Analisa sensitivitas terhadap biaya investasi dapat diketahui semakin tinggi biaya investasi maka NPV semakin kecil, semakin tinggi harga jual unit Indekos maka NPV semakin besar, semakin besar bunga pinjaman NPV semakin kecil, dan semakin berkurang okupansi penjualan unit maka NPV semakin kecil. 
Hasil analisa sensitivitas antara variabel terhadap NPV diketahui bahwa The Akavia Indekost layak jika kenaikan biaya investasi tidak lebih dari 3\%, kenaikan harga jual tidak lebih dari 3\%, kenaikan bunga pinjaman tidak lebih dari $1,5 \%$, dan occupancy penjualan unit tidak lebih dari $96 \%$.

\section{DAFTAR PUSTAKA}

[1] Hanafi, M. 2004. Manajemen Keuangan Internasional, BPFE, Yogyakarta Giatman, M.2006. Ekonomi Teknik Raja Gravindo Persada, Jakarta

[2] Sari, K. Dan Utomo, C. 2012. Analisa Pembeayaan Kerjasama Pemerintah dan Swasta pada Proyek Sidoarjo Town Square. Jurnal Teknik ITS Vol 1, No 1. Institut Teknologi Sepuluh Nopember Surabaya.

[3] Khaer, A. dan Utomo, C. 2012. Pengaruh Tingkat Hunian pada Keputusan Investasi proyek Hotel Santika Gubeng Surabaya . Jurnal Teknik ITS Vol 1, No 1. Institut Teknologi Sepuluh Nopember Surabaya.

[4] Prastiwi, dan Utomo, 2013. Kelayakan Investasi Perumahan Green Semanggi Mangrove Surabaya ditinjau dari Aspek Finansial. Jurnal Teknik ITS Vol 2, No 2. Institut Teknologi Sepuluh Nopember.

[5] Putra, M. Utomo, C. dan Nurcahyo. 2013. Analisa Pembeayaan Investasi Proyek Apartemen Puncak kertajaya. Jurnal Teknik ITS Vol 2, No 1. Institut Teknologi Sepuluh Nopember Surabaya.

[6] Nufaili, R dan Utomo, C. 2014. Analisa Investasi Hotel Pessona Makasar. Jurnal Teknik ITS Vol 3, No 2. Institut Teknologi Sepuluh Nopember Surabaya.

[7] Ningsih, M. dan Utomo, C. 2014. Analisa Investasi Apartemen Puri Park View Tower E Kebon Jeruk - Jakarta Barat. Jurnal Teknik ITS Vol 3, No 2. Institut Teknologi Sepuluh Nopember Surabaya.

[8] Syahrizal, M. dan Utomo, C. 2014. Analisa Pembeayaan Investasi Proyek Apartemen Puncak kertajaya. Jurnal Teknik ITS Vol 2, No 1. Institut Teknologi Sepuluh Nopember Surabaya.

[9] Wahyudi, O. Dan Utomo, C. 2014. Analisa Investasi pada Proyek Pembangunan Apartemen Bale Hinggil Surabaya. Jurnal Teknik ITS Vol 3, No 1. Institut Teknologi Sepuluh Nopember Surabaya.

[10] Listyaningsih, D. dan Utomo, C. 2012. Pengaruh Tingkat Keterlambatan Pembebasan Lahan Terhadap Keputusan Investasi Proyek Jalan Tol Surabaya-Mojokerto. Jurnal Teknik ITS Vol 3, No 2. Institut Teknologi Sepuluh Nopember Surabaya.

[11] Iffahni, dan Utomo. 2015. Analisa Invetasi apartemen Taman Melati. Jurnal Teknik ITS Vol 3, No 2. Institut Teknologi Sepuluh Nopember Surabaya.

[12] Maulanasari, A. dan Utomo, C. 2015. Analisa Pembiayaan Investasi Properti Perkantoran di Jakarta Selatan. Jurnal Teknik ITS Vol 4, No 2. Institut Teknologi Sepuluh Nopember Surabaya.

[13] Maulina, Z. dan Utomo, C. 2016. Study Kelayakan Investasi Apartemen Gunawangsa merr Surabaya. Jurnal Teknik ITS Vol 4 , No 2. Institut Teknologi Sepuluh Nopember Surabaya.

[14] Herwitasari, F. dan Utomo, C. 2016. Studi Pengambilan Keputusan Investasi Dengan Resiko Pada Pengembangan Proyek Caspian Tower, Gran Sungkono Lagoon Surabaya. Jurnal Teknik ITS Vol 5, No 2. Institut Teknologi Sepuluh Nopember Surabaya.

[15] Soeharto, I. 2002. Studi Kelayakan Proyek Industri. Jakarta: Erlangga 